\title{
Departures from Tradition: The Early Years Learning Framework for Australia
}

\author{
Susan Grieshaber \\ Queensland University of Technology \\ Australia
}

\begin{abstract}
In 2009, the Commonwealth Government of Australia published the first national learning framework for use with children aged birth to five years. The framework marks a departure from tradition in that it emphasizes intentional teaching, learning as well as child development, a particular type of play-based learning, outcomes, and equity. This article analyzes aspects of the document that depart from well established approaches to early childhood education in Australia and identifies challenges for educators who are required to use the document. It concludes that ongoing and supportive professional learning opportunities must accompany the introduction and enactment of the document.
\end{abstract}

Key words : learning, play-based, intentional teaching, outcomes, equity, child development

Belonging, Being \& Becoming: The Early Years Learning Framework for Australia (Commonwealth of Australia, 2009) marks several 'firsts' for Australia. It is the first national curriculum document to be published as part of the Council of Australian Governments' (COAG) agenda for the development of national curriculum documents from birth to the age of eighteen. It is also the first time that Australia has had a national curriculum document that targets children aged birth to five years. Belonging, Being and Becoming: The Early Years Learning Framework for

Correspondence concerning this article should be addressed to Susan Grieshaber, Professor, Early Years Education, School of Early Childhood, Queensland University of Technology, Victoria Park Road, Kelvin Grove 4059, Queensland, Australia. Electronic mail may be sent to s.grieshaber@qut.edu.au
Australia (Commonwealth of Australia, 2009) (the Framework) is also noteworthy because it is the first time a curriculum document has been mandated for all services in Australia that are eligible for families to receive benefits from the Commonwealth government. The Framework sits alongside a range of other reforms that are part of the Australian National Early Childhood Strategy. Significantly, curriculum documents for children in before school settings are currently being written, revised or have been published recently in a number of countries (e.g., England, Hong Kong, Korea, Sweden, Taiwan).

The Framework is based on recent international evidence that shows the importance of the early years in children's development. It begins with a number of visionary statements and its aim is "to extend and enrich children's learning from birth to five years and 
through the transition to school" (Commonwealth of Australia, 2009, p. 5). The Council of Australian Governments (COAG) developed the Framework to "assist educators to provide young children with opportunities to maximise their potential and develop a foundation for future success in learning" (p. 5). The Framework will also contribute to realising the COAG vision that "All children have the best start in life to create a better future for themselves and the nation" (p. 5). This statement indicates the influence of human capital theory and signals the importance of education in producing a labor force that generates long-term social benefits for the country. The premise is that early childhood education is a worthwhile investment because it produces good citizens and prevents potential problems in primary and secondary education and in later life (Penn, in press). Consequently, a key focus of the Framework is teaching and learning, and it aims to provide a foundation for "ensuring that children in all early childhood education and care settings experience quality teaching and learning" (p. 5). This is quite a challenge given that educators, defined as "early childhood practitioners who work directly with children in early childhood settings" (p. 5) are differently qualified (e.g., Bachelor degrees, Certificate and Diploma qualifications, some unqualified, some becoming qualified), and all are expected to use the Framework to inform their daily work with young children and their families.

In incorporating principles of the United Nations Convention on the Rights of the Child (UNCRC), the Framework recognizes that "all children have the right to an education that lays a foundation for the rest of their lives, maximizes their ability, and respects their family, cultural and other identities and languages" (Commonwealth of Australia, 2009, p. 5). Consistent with the UNCRC, the Framework also acknowledges children's "right to play and be active participants in all matters affecting their lives" (p. 5). Links are also made to the Melbourne Declaration on Education Goals for Young Australians, which include becoming "successful learners, confident and creative individuals and active and informed citizens" (p. 5). Finally, in terms of visions for Australia, early childhood education is identified as playing a major role in closing the gap between Indigenous and nonIndigenous educational achievement. This is to occur within a decade but no specific advice is provided about how it might happen. These visionary statements mark out the territory that the Framework covers.

This article analyzes key aspects of the Framework and provides a commentary about those parts of the document that depart from tradition in early childhood education in Australia. By tradition, I mean curriculum approaches that are widely used and accepted by educators working with children and families in before school settings in Australia. These include approaches informed by developmental theories and which adopt child-centered approaches that value the importance of play, discovery, and exploration, and which plan curriculum experiences around children's interests and needs. While often eclectic, these approaches tend to be inspired to different degrees by the influence of child centered curriculum (see Walkerdine, 1984), developmentally appropriate practice (Copple \& Bredekamp, 2009), emergent curriculum (Jones \& Nimmo, 1994), the principles of Reggio Emilia (Edwards, Gandini, \& Forman, 1993), and multiple intelligences (Gardner, 1993). I suggest that there are five departures from tradition and that the Framework combines an emphasis on learning and intentional teaching with features from approaches that are widely used and accepted. These five departures are:

1. 'Free' play and play-based learning;

2. Child development and learning;

3. Free play and intentional teaching;

4. Outcomes to plan learning;

5. High expectations and equity.

In what follows I discuss each departure and 
explain how the Framework combines well-known approaches with a focus on learning and intentional teaching. I also discuss implications of these changes and point out some challenges for educators in Australia in enacting the Framework in ways that are consistent with the intent of the document.

\section{'Free' play and play-based learning}

The emphasis in the Framework on free play and play-based learning is a departure from tradition because of the inclusion of play-based learning. Free play is extended time for pretend play that is mostly child initiated. It is freely chosen, personally driven and intrinsically motivated, and has characterized approaches to early childhood education for more than one hundred years, having been valued by Rousseau and Froebel, and later Piaget (Grieshaber \& McArdle, 2010). Free play is an important part of what occurs in many early childhood settings and has been endorsed as the essential element of early childhood programs because of the way it promotes children's growth and development (see Bredekamp, 1987; Johnson, Christie, \& Wardle, 2005; Wood \& Attfield, 2005). Free play suggests notions of freedom and choice, and therefore independence of children in play (Burman, 1994).

Traditionally, adults have had little involvement in free play as their role involves establishing the environment according to children's interests, needs and developmental growth. Children are then 'free' to play, grow and develop in supportive environments. Intervention from adults has the potential to interrupt the autonomy and independence that comes from the experience of free play. Where free play is valued in early childhood educational settings, children rarely make contact with teachers as "they are engaged in play or other activities chosen by themselves" (Pramling Samuelsson \& Johansson, 2009, p. 88). While the amount of time children have for free play varies according to the country (see Wagner, 2006) and the length of the program (e.g., sessional kindergarten as opposed to long day care), in Australian early childhood settings there has generally been significant amounts of time provided for children to engage in free play.

Recent research has challenged the value of free or discovery play that is child-initiated but lacks quality adult-child verbal interaction. For instance, Sylva, Melhuish, Sammons, Siraj-Blatchford, Taggart and Elliott (2003) found that in effective preschool settings in England, children were encouraged to initiate activities and that the number of child and adult initiated activities was about equal. In such settings, the extent to which adults extended child-initiated activities was highly significant. In nearly half of the child initiated activities which included intellectual challenge, adult-child verbal interaction resulted in extending children's thinking (Siraj-Blatchford \& Sylva, 2004). These effective preschool settings also managed to achieve a balance between "teacherinitiated group work" and "freely chosen, yet potentially instructive, play activities" (p. 720). The balance between adult and child-initiated play activities is important, as is the quality of adult-child verbal interaction because of the potential to enhance children's thinking and extending their learning.

Free play approaches generally adopt the position that children's interests and needs are revealed through play. Learning is considered to be more meaningful for children when it occurs through self motivation rather than via more formal or adult directed approaches. However, there is some ambiguity about whether children's interests are "themselves goals, whether children create their own goals through their interests, and if so, what those goals are" (Wood, 2007, p. 124). Further, the role of educators in recognising and acting on these interests/goals can be problematic. Wood (2007) uses the example of children playing with water to argue that playing may enable children to make pertinent observations, but

...they will not spontaneously learn the concept of 
floating and sinking, volume and mass without educative encounters with more knowledgeable others. In other words, play activities may stimulate learning-relevant processes, but may be content free, which juxtaposes the developmental against the educational rationale for play" (p. 125).

This example identifies the key differences between free play and play-based learning and highlights the importance of educators and more knowledgeable others in extending children's thinking and learning.

Informed by recent research, the Framework endorses play-based learning, which is described as "a context for learning through which children organise and make sense of their social worlds, as they engage actively with people, objects and representations" (Commonwealth of Australia, 2009, p. 6). Children are regarded as active participants and decision makers in learning, engaging with others to make meaning and contributing to the learning of others. Thus children are seen as agentic and as having the capacity to "make choices and decisions, to influence events and to have an impact on one's world" (Commonwealth of Australia, 2009, p. 45). Understanding children in these ways opens many powerful possibilities for their learning and removes ideas about limitations to children's thinking based on outdated but pervasive ideas about children's development, such as age and stage theories.

Educators are an integral part of play-based learning because they engage actively with children in play, encouraging them to make connections among ideas, concepts, processes and representations. To do this, educators need to have a good understanding of individual children's knowledge and abilities, and be able to extend their thinking in ways that are meaningful to enhance learning. For instance, the Framework (Commonwealth of Australia, 2009) encourages educators to promote learning about symbol systems and their uses in children's everyday lives. While dependent on the context and the children involved, this may involve adult initiated curriculum experiences where children aged 4-5 years are actively engaged in discussing and playing with concepts and ideas about letters, numbers, time, money and musical notation (such as talking about the patterns and relationships that exist between numerals and what they represent). Adult initiated learning experiences are an integral part of play-based learning and can be both pre-planned and take advantage of spontaneous situations occurring in children's play. However, Wood (2009) has suggested that for some educators, adult or curriculum generated play experiences are akin to adult intervention in children's play. When considered in this way, Wood says the question should be asked about "whose purposes and intentions are paramount" (p. 166); and "...what are the modes, intentions and outcomes of adult intervention" ( $p$. 166). The points made by Wood give an indication of the degree of movement that is required for some educators to embrace adult initiated play experiences.

The contrast between free play approaches and those that adopt adult or curriculum generated experiences as an integral part of early childhood curriculum has led to concerns about reduced child choice, and the idea that more 'structure' is required. However, examples from the research by SirajBlatchford and Sylva (2004) show that structure is not necessarily associated with adult generated curriculum experiences and that adults play an important role in extending children's learning through child-initiated play. Belonging, Being $\mathcal{E}$ Becoming: The Early Years Learning Framework for Australia brings together both free play and playbased learning and provides examples of how this might occur. The challenge for educators who might be used to free play, and for those involved in adult centered approaches, is to find a balance between free play and adult generated curriculum experiences and to know how to capitalize on child-initiated play to extend children's learning in play-based ways. 


\section{Child development and learning}

The second departure from tradition is the emphasis on children's learning in combination with child development. Child development perspectives that focus on the individual child's physical, social, emotional and cognitive growth and development have dominated early childhood education for many years (Burman, 2008). During this time, educators have relied on theories of child development to assist in understanding children's behaviour and for planning early childhood programs. However, there has been apprehension for some time about the value and place of child and developmental psychology in early childhood education. Some of these concerns include:

- The focus on the individual child, as opposed to locating children in social, cultural and political contexts (Lubeck, 1994);

- The idea that if developmental theory is normative, then by implication those children who do not fit developmental milestones are not 'normal' (Cannella, 1997);

- The assumption of universal patterns of development through which all children pass at about the same ages (Burman, 1994; Cannella, 1997); and

- The idea that children are an immature form of adult and are in the process of becoming fully competent adults. (Silin, 1995)

Despite these concerns and their accompanying critiques, developmental psychology has remained highly influential in providing understandings of children's behaviour and for educators planning programs for young children. Alternative theoretical perspectives have found their way into the field but the influence and dominance of child developmental theories remains strong.

Belonging, Being and Becoming: The Early Years Learning Framework for Australia (Commonwealth of Australia, 2009) brings together children's development and an emphasis on children's learning in ways that generally are not seen where child development remains the focal point of early childhood programs. The Framework attaches significant weight to the importance of learning. For instance, the document is a 'learning' Framework; it incorporates 'A vision for children's learning'; it identifies a set of learning outcomes for children; and where both 'development' and 'learning' are mentioned, in nearly all cases, the word 'learning' precedes the word 'development' (p. 7 provides an exception). The influence of recent research is evident in naming content areas as communication and language (including early literacy and numeracy) and social and emotional development. For instance, case studies in the English study of the Effective Provision of Pre-school Education (EPPE) (Sylva et al., 2003) revealed that where cognitive and social development were seen as complementary, settings achieved the best outcomes for children. In the most effective settings, children were provided with "more experience of curriculum-related activities (especially language and mathematics)" (p. 5), and were encouraged to "engage in activities with higher intellectual challenges" (p. 5). The EPPE study also revealed that the curriculum content knowledge of educators makes a difference to children's learning, as does knowledge of strategies for promoting content knowledge (Sylva et al., 2003). Moreover, curriculum content knowledge is just as important in the early years as it is in the middle and upper years of schooling. Despite recognition of the importance of content knowledge and knowing how to teach it, there has been some opposition to it being emphasised in programs for young children.

Resistance to a focus on content knowledge has come from Adams, Alexander, Drummond and Moyles (2004) and Moyles, Adams, and Musgrove (2002), who have claimed such a focus has reduced opportunities for children to develop independence and be spontaneous in their learning; and diminished opportunities for children's free choice, play-based activities and first-hand experiences. These are all 
features of approaches to early childhood education that value free play. Emphasising children's learning in addition to well-known child development perspectives is a distinct change for many in the field of early childhood education in Australia. However, the best outcomes for children come from settings where child development and learning work together to complement each other (Sylva et al., 2003). This means educators being knowledgeable about curriculum content areas and knowing how to extend children's learning through complementary pedagogical approaches.

Moving from considering child development as the content of early childhood curriculum (physical, emotional, social and cognitive development) to something that is more discipline based (e.g., language and communication, literacy and numeracy) fits well with play-based approaches to learning (as discussed in the previous section: Free play and playbased learning). Educators who have always focused on children's growth and development will need time to transition to thinking in content as well as developmental areas. Professional development is essential for those in this situation, and as indicated by Sylva et al. (2003), educators may need support in developing content area knowledge as well as ways of introducing it to children. As might be expected, the EPPE research showed that qualified staff provided more curriculum related activities and encouraged children to become involved in activities with higher intellectual challenges (Sylva et al., 2003). Predictably, the most highly qualified staff engaged in the most direct teaching, were the most effective in interacting with children and used the most sustained shared thinking (Sylva et al., 2003; see section about Free play and intentional teaching). Further, and of significance for the Australian situation, is the finding that less qualified staff were "significantly better as pedagogues when they worked with qualified teachers" (p. 5).

\section{Free play and intentional teaching}

A learning Framework that emphasizes intentional teaching marks another departure from tradition because it focuses on teaching, learning and child development, rather than being oriented primarily to children's developmental progress. Where free play is a feature of early childhood programs, child autonomy (or the lack of adult intervention) works to encourage children's curiosity, foster confidence, and develop competence and independence. Educators establish the environment and 'facilitate' development by responding to children's interests, needs and abilities, which have been revealed through the observation of play and other childinitiated activities. Children's developmental 'readiness' is used as a guide for the introduction of aspects of literacy and numeracy (Wood, 2007). However, recent debates have challenged noninterventionist and reactive roles of adults in children's play (e.g., Johnson et al., 2005; SirajBlatchford, \& Sylva, 2004; Sylva et al., 2003; Wood \& Attfield, 2005).

One of the key weaknesses of developmental approaches is that curriculum content emerges through the needs and interests of the children (Darling, 1994). As Wood (2007) points out, showing an interest in something (which is often serendipitous) is quite different from engaging meaningfully in a process that results in the acquisition of knowledge and skills. This example of passing interest is characteristic of free play approaches where activities are a feature of the program and often change on a daily basis, and the emphasis is the process rather than the product. Alternatively, prolonged investigation, either adult or child-initiated, nested within a curriculum framework that identifies content knowledge and which is accompanied by pedagogical knowledge, has a much greater chance of engaging children in meaningful learning and extending their knowledge. A related difficulty is the lack of differentiation between 
learning and development. According to Wood (2007), in approaches where education is seen as development, the terms development and learning are "often used interchangeably" and there is "inadequate engagement in debate about what forms of socially valued knowledge children might usefully engage with...and insufficient clarification of proactive pedagogical approaches" (p. 123). The Framework makes a clear distinction between development and learning, and while endorsing both, privileges learning. It also names pedagogical approaches and draws links between content, pedagogical approaches and extending children's learning.

The value of high quality adult-child verbal interactions was shown in the EPPE study through the idea of 'sustained shared thinking' (SirajBlatchford \& Sylva, 2004). Sustained shared thinking occurs where "two or more individuals 'work together' in an intellectual way to solve a problem, clarify a concept, evaluate an activity, extend a narrative...Both parties must contribute to the thinking and it must develop and extend the understanding" (Sylva et al., 2003, p. 4). Significantly, the most common critical point for "lifting the level of thinking' occurred when a practitioner 'extended' a child-initiated episode by scaffolding, thematic conversation or instruction" (Siraj-Blatchford \& Sylva, 2004, p. 723). The most effective settings in the EPPE study encouraged sustained shared thinking, which was most likely to occur when children were interacting in a one-to-one situation with an adult or peer (Sylva et al., 2003).

Intentional teaching is one way of encouraging sustained shared thinking. The strategies for intentional teaching identified in the Framework are consistent with those involved in sustained shared thinking. Siraj-Blatchford and Sylva (2004) recommend that adults plan to interact with children in focused ways to encourage sustained shared thinking. They found that in creating sustained shared thinking, worksheets and didactic approaches were of little value as it was freely chosen play activities that offered the best opportunities for adults to extend children's thinking. Along with sustained shared thinking, knowledge and understanding of the content of the curriculum and complementary pedagogical approaches are essential for promoting children's learning. Thus, intentional teaching is integral to play environments but it is the combination of intentional teaching with "freely chosen yet potentially instructive play activities" that makes a difference to children's learning (Sylva et al., 2003, p. 5).

The Early Years Learning Framework for Australia (Commonwealth of Australia, 2009) conceptualises adult roles as both proactive and responsive. It endorses the responsive roles of adults that characterize emergent curriculum and child centered approaches, and at the same time emphasizes intentional teaching. The Framework describes intentional teaching as involving "educators being deliberate, purposeful and thoughtful in their decisions and action. Intentional teaching is the opposite of teaching by rote or continuing with traditions simply because things have 'always been' done that way" (p. 15). It includes the purposeful selection of pedagogical strategies, which are aimed specifically at children's learning. Intentional teaching then, involves planning opportunities for learning but also capitalizing on spontaneous events or what is occurring 'in the moment'. Thus the social context of learning is highly influential and educators are encouraged to actively promote learning that challenges children experientially and intellectually through everyday interaction and conversation 'in the moment'. A range of strategies is used in intentional teaching: "modelling and demonstrating, open questioning, speculating, explaining, engaging in shared thinking and problem solving to extend children's thinking and learning" (p. 15). Opportunities for intentional teaching and knowledge-building are both planned and spontaneous, and learning is documented and monitored as an integral part of knowledge building. 
Intentional teaching marks a departure from tradition because for most of the twentieth century, the focus of research in early childhood education has been "the development of children - not the practices of teachers" (Genishi, Ryan, Ochsner, \& Yarnall, 2001, p. 1179). Concentrating research on the growth and development of children has not only resulted in a dearth of research that investigates early childhood educators and their teaching approaches and practices, but it has also minimized and undervalued the role of educators in children's learning, and in some cases compromised the potential to children to learn. The Framework accentuates the role of educators in intentional teaching. The challenge for educators is to learn how to balance intentional teaching and free play approaches in ways that promote children's educational progress and achievement (rather than development alone).

\section{Outcomes}

The fourth departure from tradition is the inclusion of outcomes. The Framework challenges widely accepted views of free play and non-intervention by educators in children's play by adopting learning outcomes. The learning outcomes take up the majority of the document, with 25 of the 47 pages devoted to descriptions of each of the five outcomes. While the compulsory education sector in Australian states and territories has used outcomes based approaches since the early 1990s, they are a new addition to early childhood curricula and a major change for early childhood educators in Australia. The achievement of outcomes is usually determined by students demonstrating 'what they know and can do' when measured against pre-established standards. Adopting outcomes is a way of ensuring that the content and skills covered by the measurable standards will be a major focus in the education of students. The Framework describes a learning outcome as "a skill, knowledge or disposition that educators can actively promote in early childhood settings, in collaboration with children and families" (Commonwealth of Australia, 2009, p. 8).

There is a long history of privileging free play in early childhood education settings in Australia. In such approaches, the adage is to start with the child. In outcomes based education, outcomes are the starting point in that the first thing to be decided is the knowledge and skills that are to be demonstrated or achieved by the end of the process. Then, working backwards, a curriculum is developed based on the knowledge and skills required by students on exiting the system. The curriculum is accompanied by resources and strategies to help students achieve the outcomes. Belonging, Being \& Becoming: The Early Years Learning Framework for Australia (Commonwealth of Australia, 2009) includes aspects of transitional outcomes based education (Spady, 1993) because it focuses on lifelong learning and values problem solving and communication skills. For instance, Outcome 5 is Children are effective communicators; and part of the vision is that "All children experience learning that is engaging and builds success for life" (Commonwealth of Australia, 2009, p. 7). The Framework also adopts a transformational approach to outcomes based education (Spady, 1993), which is evident in the future oriented nature of the outcomes (e.g., lifelong learning, p. 16; p. 33) as well as the emphasis on undertaking tasks in real life. For example, Outcome 2 states: Children are connected with and contribute to their world; and Outcome 4 is: Children are confident and involved learners. Being confident and involved learners is important for lifelong learning ( $p$. 33).

The five outcomes are "broad and observable" (Commonwealth of Australia, 2009, p. 19), are strengths based, focus on lifelong learning dispositions, recognize that children learn in different ways, promote high expectations and equity, and include a number of key indicators listed under each outcome. They also incorporate examples of how educators can promote children's learning and 
"evidence that educators may observe in children as they learn" (p. 19). There is no expectation that children engaged in specific activities would be 'assessed' against key indicators, as the outcomes are broad and holistic. Contrary to starting with the outcomes as is customary in outcomes based education, the Framework advises educators to "plan with each child and the outcomes in mind" (Commonwealth of Australia, 2009, p. 19). The simultaneous focus on the child and the outcomes may allay some concerns about children's play and learning being limited to achieving defined learning outcomes (see Wood, 2007). However, there remains a tension between the notion of free play and the way in which outcomes can be used instrumentally to achieve specific educational ends (Wood, 2009).

The Early Years Learning Framework (Commonwealth of Australia, 2009) is consistent with contemporary theoretical advances in that it adopts a position that integrates play, learning and teaching. The inclusion of outcomes has created a need for early childhood educators to develop strategies and approaches that fuse a nexus between play-based learning and outcomes. Challenges in getting play-based learning and outcomes to work together include knowing individual children and the outcomes well enough to develop reciprocal understandings of children and outcomes, and how each informs the other. That is, how to use knowledge of individual children to identify progress according to the outcomes; and, knowing the outcomes well enough to enhance and extend children's learning in planned and spontaneous situations. The skill of educators in achieving this is pivotal, as is the necessity to resist considering the outcomes as isolated from in-depth knowledge and understanding of children.

\section{High expectations and equity}

The fifth departure from tradition is the significant place accorded to high expectations and equity in the
Framework. High expectations and equity are one of the five principles on which the Framework is based. The expectation is that all children can succeed, "regardless of diverse circumstances and abilities" (Commonwealth of Australia, 2009, p. 12). When educators have clear goals, high expectations and knowledge of the skills and dispositions needed for learning and successful transition to school, children make more progress in literacy, numeracy, independence, cooperation, and social development (Thorpe et al., 2004). Holding high expectations for all children's success in learning is reflected in the outcomes statements (e.g., Outcome 1, p. 22; Outcome 3 , p. 31). Having high expectations that all children can succeed in learning means a focus by educators on children's learning and that educators are proactive in leading children's learning; all the while maintaining a balance between adult initiated and child initiated learning opportunities.

Equity is an integral part of the vision of the Framework and contrary to many early childhood curriculum documents, the Framework recognizes the contribution of poststructuralist theories to issues of "power, equity and social justice in early childhood settings" (Commonwealth of Australia, 2009, p. 11). In appreciating that the focus on equity might be novel, early childhood educators are encouraged to "find new ways of working fairly and justly" (p. 11). However, the challenge is for understandings of equity to be reflected in the everyday language used by early childhood educators when interacting with children, their families and professional colleagues. Equitable approaches demand that all children are provided with interesting and varied teaching because it produces sustained engagement. Sustained engagement enhances and extends children's learning (Siraj-Blatchford \& Sylva, 2004). Attention to equity also means that educators are aware and prevent situations occurring where "...students with poor skills may get less interesting and challenging instruction" (Levin, 2008, p. 124). Equity relates specifically to the concepts of Belonging Being $\mathcal{E}$ 
Becoming and the provision of a "...safe environment, sense of belonging and adult care," and the affirmation of "...diverse student identities" (Levin, 2008, p. 115). Affirming diverse student identities is fundamental in creating a safe environment and a sense of belonging and adult care, and occurs through developing "...greater cultural awareness among staff of the real lives of students, outreach to minority students, early intervention and support for students experiencing difficulty" (Levin, 2008, p. 117).

As part of achieving the vision of equity, educators are encouraged to draw on a range of theoretical perspectives to "challenge traditional ways of seeing children, teaching and learning" (Commonwealth of Australia, 2009, p. 11). Ongoing learning and reflective practice are ways in which the Framework suggests that this can be initiated. To this end, educators are provided with a range of provoking but overarching questions which act as focal points for reflective practice. Examples include:

- Who is advantaged when I work in particular ways and use particular theoretical perspectives? Who is disadvantaged?

- What aspects of my work are not helped by the theories and guidance that I usually draw on to make sense of what I do? (p. 13)

\section{Conclusion}

Belonging, Being \& Becoming: The Early Years Learning Framework for Australia (Commonwealth of Australia, 2009) marks several departures from tradition in early childhood education in Australia. It endorses adult or curriculum generated learning and child-initiated play through play-based learning. The strategy is to find ways in which adult or curriculum generated play based learning can complement child initiated or free play to enhance children's learning. While learning is the focus of the Framework, finding a balance between content and developmental areas establishes a new direction for some early childhood educators. Similarly, with intentional teaching, the quest is to learn how to balance intentional teaching and free play in ways that promote children's educational progress and achievement, rather than focusing on primarily on development. Outcomes are a new addition to early childhood curricula, and their inclusion in the Framework has created opportunities for early childhood educators to learn how play based learning and outcomes can complement each other to further the goal of children's learning. Having high expectations that all children will succeed in learning embodies the principles of equity that permeate the document. The mandatory nature of the document intensifies the obligation to provide high quality professional learning opportunities, particularly for those less qualified educators who might be encountering intentional teaching, discipline based content, outcomes, equity or play-based learning for the first time.

\section{References}

Adams, S., Alexander, E., Drummond, M. J., \& Moyles, J. (2004). Insider the foundation stage: Recreating the reception year. London: Association of Teachers and Lecturers.

Arthur, L., Beecher, B., Death, E., Dockett, S., \& Farmer, S. (2008). Programming and planning in early childhood settings (4th ed.). Melbourne: Nelson Australia.

Bredekamp, S. (Ed.). (1987). Developmentally appropriate practice in early childhood programs serving children from birth through age 8 (Expanded ed.). Washington, DC: National Association for the Education of Young Children.

Bredekamp, S., \& Copple, C. (Eds.). (1997). Developmentally appropriate practice in early childhood programs (Rev. ed.). Washington, DC: National Association for the Education of Young Children.

Burman, E. (1994). Deconstructing developmental 
psychology. London: Routledge.

Burman, E. (2008). Deconstructing developmental psychology (2nd ed.). London: Routledge.

Cannella, G. S. (1997). Deconstructing early childhood education: Social justice and revolution. New York: Peter Lang.

Commonwealth of Australia. (2009). Belonging, being \& becoming: The early years learning framework for Australia. Canberra, ACT: Department of Education, Employment and Workplace Relations for the Council of Australian Governments.

Copple, C., \& Bredekamp, S. (2009). (Eds.). Developmentally appropriate practice in early childhood programs serving children from birth through age 8 (3rd ed.). Washington, DC: National Association for the Education of Young Children.

Darling, J. (1994). Child-centred education and its critics. London: Paul Chapman.

Edwards, C., Gandini, S., \& Forman, G. (1998). The hundred languages of children: the Reggio Emilia approach to early childhood education (2nd ed.). Norwood, NJ: Ablex.

Genishi, C., Ryan, S., Ochsner, M., \& Yarnall, M. (2001). Teaching in early childhood education: Understanding practices through research and theory. In V. Richardson (Ed.), Handbook of research on teaching (4th ed., pp. 1175-1120). Washington, DC: American Educational Research Association.

Grieshaber, S. (2008). Interrupting stereotypes: Teaching and the education of young children. Early Education and Development, 19(3), 505-518.

Grieshaber, S., \& McArdle, F. (2010). The trouble with play. Maidenhead: Open University Press.

Johnson, J. E., Christie, J. F., \& Wardle, F. (2005). Play, development and early education. Boston: Pearson Education.

Jones, E., Evans, K., \& Renken, K. S. (2001). The lively kindergarten: Emergent curriculum in action. Washington, DC: National Association for the Education of Young Children.
Jones, E., \& Nimmo, J. (1994). Emergent curriculum. Washington, DC: National Association for the Education of Young Children.

Levin, B. (2008). An approach to secondary school improvement. In A. Luke, K. Weir, \& A. Woods (Eds.), Development of a set of principles to guide a P12 syllabus framework: A Report to the Queensland Studies Authority, Queensland, Australia (pp. 114127). Brisbane, Australia: The State of Queensland (Queensland Studies Authority).

Lubeck, S. (1994). The politics of developmentally appropriate practice: Exploring issues of culture, class and curriculum. In B. L. Mallory, \& R. S. New (Eds.), Diversity and developmentally appropriate practices: Challenges for early childhood education (pp.17-43). New York: Teachers College Press.

Moyles, J., Adams, S., \& Musgrove, A. (2002). SPEEL: Study of pedagogical effectiveness in early learning (Research Report No. 363). London: Department for Education and Skills.

Penn, H. (in press). Quality in early childhood services: An international perspective. Maidenhead: Open University Press.

Pramling Samuelsson, I., \& Johansson, E. (2009). Why do children involve teachers in their play and learning. European Early Childhood Education Research Journal, 17(1), 77-94.

Silin, J. G. (1995). Sex death and the education of children: Our passion for ignorance in the age of aids. New York: Teachers College Press.

Siraj-Blatchford, I., \& Sylva, K. (2004). Researching pedagogy in English pre-schools. British Educational Research Journal, 30(5), 712-730.

Spady, W. (1993). Outcome based education. Belconnen, ACT: Australian Curriculum Studies Association.

Sylva, K., Melhuish, E., Sammons, P., Siraj-Blatchford, I., Taggart, B., \& Elliott, K. (2003). The effective provision of pre-school education (EPPE) project: Findings from the pre-school period (Research Brief No. RBX15-03). London: Department for Education and Skills. 
Thorpe, K., Tayler, C., Bridgstock, R., Grieshaber, S., Skoien, P., Danby, S., et al. (2004). Preparing for school: Report of the Queensland preparing for school trials 2003/4. Brisbane, Australia: Department of Education and the Arts.

Wagner, J. T. (2006). An outsider's perspective: Childhoods and early childhood education in the Nordic countries. In J. Einarsdottir \& J. T. Wagner (Eds.), Nordic childhoods and early education: Philosophy, research, policy and practice in Denmark, Finland, Iceland, Norway, and Sweden (pp. 289-306). Greenwich, CT: Information Age Publishing.

Walkerdine, V. (1984). Developmental psychology and the child-centred pedagogy: The insertion of Piaget into early education. In J. Henriques, W. Hollway, C. Urwin, C. Venn \& V. Walkerdine (Eds.), Changing the subject: Psychology, social regulation and subjectivity (pp.153-202). London: Methuen. Wood, E. (2007). Reconceptualising child-centred education: Contemporary directions in policy, theory and practice in early childhood. Forum, 49(1\&2), 119-133.

Wood, E. (2009). Conceptualising a pedagogy of play: international perspectives from theory, policy and practice. In D. Kuschner (Ed.), From children to red hatters®: Diverse images and issues of play. Play \& culture studies, Vol. 8 (pp. 166-189). Lanham: University Press of America.

Wood, E., \& Attfield, J. (2005). Play, learning and the early childhood curriculum (2nd ed.). London: Sage. 